\title{
Special Allocation Fund-Efficiency Energy (DAK-EE) an Acceleration of Energy Efficiency in Indonesia
}

\author{
Joko Tri Haryanto ${ }^{a^{*}}$ \\ ${ }^{a}$ Centre for Climate Change Financing and Multilateral Policy, Fiscal Policy Office-Ministry of Finance of Indonesia
}

\begin{abstract}
Related to climate change and economic development of environmentally friendly (green economy) issues, the President has committed to reducing emissions of greenhouse gases (GHG) by $26 \%$ on their own sources (BAU), and up to $41 \%$ with international support in 2020 through Presidential Decree No. 61 in 2011 about the National Action Plan for Greenhouse Gas Emission Reduction (RAN-GRK). In addition to regulating the sectors that are considered to be the largest contributor to GHG emissions, the regulation also establishes funding sources RAN-GRK either through the APBN, APBD, as well as a variety of other sources constituted under the legislation.

One of the initiatives that need to be supported is an effort to reduce their energy use. In this context, the Ministry of Finance has provided various forms of incentives to affect various economic actors in order to implement energy savings programs through the Special Allocation Fund (DAK) Energy Efficiency (EE) in the mechanism of Transfer to Regions. DAK-EE is expected to occur in energy efficiency projects aimed to (1) reduce electricity subsidies, (2) encourage the use of energy-efficient technologies, (3) stimulating the involvement of the financial sector (banking / financial institutions) to support the development of energy conservation and, (4) assist efforts to achieve national GHG emission reduction target by 2020 .

Using the descriptive method of analysis, the researcher wanted to analyze the possible use of DAK EE as a energy efficiency financing in Indonesia.
\end{abstract}

Keywords: Special Allocation Fund, Energy Conservation, Energy Efficiency

\section{Introduction}

Related to climate change and economic development of environmentally friendly (green economy) issues, the President has committed to reducing emissions of greenhouse gases (GHG) by $26 \%$ on their own sources (BAU), and up to $41 \%$ with international support in 2020 through Presidential Decree No. 61 in 2011 about the National Action Plan for Greenhouse Gas Emission Reduction (RAN-GRK). In addition to regulating the sectors that are considered to be the largest contributor to GHG emissions, the regulation also establishes funding sources RAN-GRK either through the APBN, APBD, as well as a variety of other sources constituted under the legislation.

On the other hand, the burden of energy subsidies in the APBN continues to increase every year. As the fiscal authorities, the Ministry of Finance have to make efforts in order to nourish the APBN. One of the initiatives that need to be supported is an effort to reduce their energy use. In this context, the Ministry of Finance has provided various forms of incentives to affect various economic actors in order to implement energy savings programs are self-sustaining facilities such as tax incentives and import duties for components and raw materials used to produce energy-efficient appliances.

However, these incentives have not been fully influence behavior change in the community and business energy use. Responding to this issue, the expansion is still needed fiscal support in the form of another. One form of fiscal support that is expected by the market participants in order to encourage investment in capital equipment, which is also a best practice in many countries, is funding the scheme

\footnotetext{
* Corresponding Author:

Email: djohar78@gmail.com
} 
through the Special Allocation Fund (DAK) Energy Efficiency in the mechanism of Transfer to Regions.

In general, DAK has advantages compared to other Regional Transfer component either DAU or DBH, especially if associated with budget allocation specification purposes. Some DAK scheme was already allocated to the sector GHG emission reductions already have DAK funding, such as forestry, agriculture, and environmental sectors. In terms of funding through DAK characteristics, which are focused on the physical activity, as well as the general focus of activity is the activity performed and the affairs of the district and city governments, the context of the funding through the complementary function of DAK funding through Grants.

Within this framework, mechanisms DAK-Energy Efficiency (DAK-EE) is expected not only to encourage investment in projects that are energy efficient, but also can have a positive impact on the reduction of energy subsidies through the efficient use of energy and reduction of greenhouse gas emissions in Indonesia. DAK-EE is expected to occur in energy efficiency projects aimed to (1) reduce electricity subsidies, (2) encourage the use of energy-efficient technologies, (3) stimulating the involvement of the financial sector (banking / financial institutions) to support the development of energy conservation and, (4) assist efforts to achieve national GHG emission reduction target by 2020 .

Energy conservation activities are expected to contribute to the reduction of GHG emissions by 22:29 million $\mathrm{tCO} 2$ by 2020. DAK-EE policy proposal is in line with the program that is being developed by the Ministry of Energy and Mineral Resources. In this regard, the Ministry of Energy in order to improve the implementation of energy conservation in the industrial and building sectors have implemented Partnership Program that provides services and capacity building energy audits free of charge to companies committed to implementing energy audit recommendations.

The main research questions on this paper are; a) special allocation fund (DAK) can be used to fund energy efficiency?; b) if so, what procedure should be done?; c) how monitoring and evaluation of the energy efficiency of the use of DAK?

This paper focuses on the mechanism of DAK for financing energy efficiency and how to build monitoring and evaluation to ensure DAK more efficient and efective.

\section{Literature Review}

In general, the concept of energy efficiency is defined as the ratio of energy needs devided by input energy. One of the concept that support energy efficiency is called Trias Energetica Concept. This simple and logical concept can be applied as an effort to achieve energy savings as well as to reduce the reliance on fossil fuel in the context of saving the environment.

There are 3 fundamental elements of trias energetica concepts i.e. reduce energy demand as much as possible by implementing energy saving measures, utilize renewable energy sources, and use fossil energy as efficiently as possible and only if sustainable sources are inadequate.

There were many studies had been discussed about the concepts of energy efficiency. According to Lovin (1976) the concept of energy efficiency can be defined as the economical usage of energy in order to increase the economic output. In the study, Lovin explaining a large number of energy alternatives, renewable, and more environmentally energy compare to fossil fuel.

Soon after its publication, various ideas about energy efficiency began having a significant effect on public policy concept (Golove and Eto, 1996). According to Adam (2004), energy efficiency is defined as how much energy services should be prepared per unit of energy input.

Related to economic problems, the economics of energy efficiency is about the question of balancing the costs and benefits. In addition to that, Golove and Eto (1996) mentioned that energy efficiency defined as providing equivalent energy service at lower total cost. There are some debates on energy efficiency due to consumer decisions over energy use.

According to Sanstad and Howarth (1994) the behaviour of energy consumers in deciding energy use is depending on maximization preference. Adam (2004) observed that personal energy user have some considerations i.e. a greater initial cost in buying energy-efficient products over expectation of future cost saving benefit. Other findings from Robinson (1991) the costs and benefits of energy efficiency labelling does not ameliorate decision making of energy user.

Moreover, Stern (1986) observed that individuals tend to overvalue the amounts of energy used and technology saved. Another study, Kirsch (1993) discovered that people who do not understand 
numerical calculations seems difficult to arrive at a right energy-related decisions.

Another debates on energy efficiency is regarding the market barriers. Blumstein, et al. (1980) observed that energy conservation actions probably hampered by social and institutional barriers, even though there are economically logical responses to the energy crises.

According to Golove and Eto (1996) there are at least seven market barriers were identified: 1) misplaced incentives, 2) lack of access to financing, 3) flaws in market structure, 4) mis-pricing imposed by regulation, 5) decision influenced by custom, and 6) lack of information or misinformation, 7) gold plating and Inseparability of Features. Therefore, decision makers need a mix of sound analysis and pragmatism to establish a good energy efficiency policy.

Except the energy efficiency concepts from various researches and studies, the GoI has its own definition in regards of energy efficiency concept. According to Government Regulation No. 70 Year 2009 regarding Energy Conservation, the definition of Energy Conservation is systematic efforts, well-planned and integrated in order to conserve domestic energy resources as well as to enhance the efficiency utilization. Efficiency constitutes one of the implementation step in achieving energy conservation. Energy efficiency generally defined as energy savings.

There are four types of intergovernmental transfer introduced in the law 32/2004 and 33/2004: natural resources revenue sharing, tax sharing, general allocation fund, and special allocation fund. Among these four types, the general allocation fund may be the most significant for almost all local governments in Indonesia, while the natural resources revenue sharing only matters for few provinces or districts.

Special allocation fund could be classified as a conditional grant in which local governments will receive the grant if the central government asks them to do certain tasks. Those certain tasks are mostly the central government's interests or in other words, the central government can use the special allocation fund to direct the regional development in order to fulfill their macro target.

According to the government regulation, this fund can be utilized to improve inter-districts roads, to help the local governments to reach minimum standard of basic services (basic education, water distribution, and health services), to support irrigation system and transmigration program, to overcome environmental problems, and to give special assistance to very poor areas.

In the government regulation, it is stated that the amount of special allocation fund depends on the existing fiscal condition. The slow recovery of national economic condition forced the central government to make a conservative budget that focuses more on necessary items such as general allocation fund and neglects, at least temporarily, the special allocation fund.

For the every fiscal year, the special allocation fund can only be utilized to protect the environment through the reforestation fund that used to be a non-budgetary fund but now becomes a part of the special allocation fund (Brodjonegoro, 2001).

\section{Research Methodology}

This paper aims to finding mechanism to accelerating energy efficiency through special allocation fund. Library research, cross sectional collection of data for intensive analysis, interviews to some leading experts in the field and a number of Focused Group Discussions were also conducted to construct the policy analysis. Collections of information are compared and developed in order to create a new mechanism to build mechanism of Special Allocation Fund for Energy Efficiency (DAK-EE).

\section{Discussion and analysis}

\section{- General Information}

Special Allocatin Fund (DAK) allocated to help fund the program in the region / activities under the authority of local and national priorities. DAK is a regional destination that can provide infrastructure facilities and infrastructure are adequate public services in accordance with Minimum Service Standards each field. DAK allocated based on three criteria, namely: (1) Common Criteria, (2) Specific Criteria and (3) Technical Criteria. General criteria calculated to see the ability to finance budget needs in the context of regional development reflected from the general revenue budget reduced personnel expenses. In formula form, the general criteria can be shown in some equations below; 
Fiscal Capacity : General Revenue (APBD) Apparatus Expenses

General Revenue (APBD): Local Own Revenue + General Allocation Fund + Revenue Sharing

Act 33 of 2004 on Fiscal Balance Between Central Government and Local Government Article 40 Paragraph 3 explains that "specific criteria established by observing the rules legislation and regional characteristics ", and added through Government Regulation No. 55 Year 2005 on Fund Balance Article 56 Paragraph 2. "Specific criteria formulated through regional index by the Minister of Finance to consider input from the Minister of Bappenas and Line Ministry.

Specific criteria are used in the calculation DAK allocation of attention: Regulation Legislation a special area; entire district / city in the province of Papua, West Papua province, and Regional backward / remote, and characteristics areas that include coastal areas and / or small islands, regions borders with other countries, disaster-prone areas, entry areas persistence in the category of food, and tourism regions. Provision data on the specificity of the Minister of Finance to coordinate regional with related institutions.

Technical criteria are criteria that reflect the condition of facilities and infrastructure of each field. Areas of facilities and conditions poor infrastructure will be prioritized to get DAK. The criteria set by the relevant technical ministries. In DAK allocation calculations, the amount of technical criteria formulated as index technical fiscal (IFT).

In 2006, DAK allocated for 9 sectors, namely education, health, roads, irrigation, drinking water, infrastructure, government, marine and fisheries, agriculture and the environment. Subsequently, in the year 2008 increased two areas, namely the field of family planning (FP) and forestry. For 2009 increased two areas also are trade and rural areas of infrastructure, so into 13 fields.

With the drinking water separation and DAK DAK sanitation in the previous year standing in a field, then DAK field in 2010 to 14 fields. DAK field in in 2011 increased to 19 fields. As for the additional 5 new fields that rural electric field, housing and settlements, land transport safety, transport rural infrastructure and border areas.

\section{- Planning and Allocation Mechanism for DAK}

In this planning and allocation mechanism for DAK consist of several activity such are: 1) setting of program and activities; 2) DAK simulation; 3) determination of the allocation and the use of Special Allocation Fund; 4) budgeting of Special Allocation Fund.

For the activity 1, we should stated DAK allocated in the state budget according to national priority programs contained in the budget RKP concerned. Line Ministry proposes special activities that will be funded from the DAK and determined after coordination with the Minister of Home Affairs, Ministry of Finance, and Minister of State for National Development Planning, in accordance with the RKP.

For the 2nd step, DAK calculation is done through two phases; determination of the specific areas that receive DAK and also determination of the amount of DAK allocation of each area. Determination of Specific Areas must meet the general criteria, specific criteria and technical criteria. DAK allocation amount of each region is determined by calculating an index based on the general criteria, specific criteria and technical criteria.

Figure 1. DAK Allocation
\begin{tabular}{|c|c|}
\hline \multicolumn{2}{|c|}{ TA } \\
\hline 2006 & 112.88 \\
\hline 2007 & 351.61 \\
\hline 2008 & 351.61 \\
\hline 2009 & 351.61 \\
\hline 2010 & 351.61 \\
\hline 2011 & 400.00 \\
\hline 2012 & 479.73 \\
\hline 2013 & 530.55 \\
\hline
\end{tabular}

For the rest activities, we can describes that DAK allocation per area defined by the Regulation of the Minister of Finance issued shortly after the State Budget Law. Based on the determination of DAK allocation, Line Ministry prepare Technical Guidelines for Use of DAK, no later than 2 weeks after the PMK set. Areas receiving it shall state the allocation and use of DAK in the budget. DAK can be done in accordance with the Technical Instructions DAK.

DAK can not be used to fund the administration of the activities, preparation of physical activities, research, training, and business travel DAK allocation amount of each region is determined by calculating an 
index based on the general criteria, specific criteria and technical criteria.

\section{Conclusion}

Based on the analysis of the mechanism of transfer to the regions in Indonesia, it is possible to enlarge of DAK field for energy efficiency by asking Line Minister to proposed mechanism and send to the Ministry of Finance. This can be addressed to support the achievement of environmentally friendly activities and reduce the burden of state budget subsidies. Some of the things that must be done is to propose the allocation of DAK EE into government programs and to develop a variety of specialized and technical indicators related.

\section{References}

Blumstein, C., B. Kreig, L. Schipper, and C. York 1980. "Overcoming Social and Institutional Barriers to Energy Efficiency."

ICA 2010, Sustainable Electrical Energy, The Business Case for Electrical Energy Efficiency in Japan

Jaffe, Adam., Newell, Richard. Stavins, Robert. 2004 "Economics of Energy Efficiency"

Kirsch, I. 1993. Adult Literacy in America: A First Look at the Results of the National Adult Literacy Survey

Lovins, A. 1976. "Energy Strategy: The Road Not Taken?"

Robinson, J.B. 1991. "The Proof of the Pudding: Making Energy Efficiency Work." Energy Policy

Sanstad, A.H. and R.B. Howarth 1994. "'Normal' Markets, Market Imperfections, and Energy Efficiency." Energy Policy

Stern, P.C. 1986. "Blind Spots in Policy Analysis: What Economics Doesn't Say about Energy Use." Journal of Policy Analysis and Management

Takahashi M and H Asano, 2011, An Assessment Study of Energy Efficiency Policy Measures for Japanese Commercial Sector, The Energy Journal, Special Issue. Strategies for Mitigating Climate Change Through Energy Efficiency: A Multi-Model Perspective

William H. Golove and Joseph H. Eto 1996. "Market Barriers to Energy Efficiency: A Critical Reappraisal of the Rationale for Public Policies to Promote Energy Efficiency"

Agency for Natural Resources and Energy (ANRE) 2012, Energy While Paper 2012,

ANRE, 2011, Status of the enforcement of the Energy Conservation Act for factories and other sectors.16th Energy Efficiency Standards Subcommittee.

A.K. van Harmelen and M.A. Uyterlinde, 1998, Integrated Evaluation of Energy Conservation Options and Instruments, A Country Comparison, The Netherlands Energy Research Foundation ECN

Asia-Pacific Economic Cooperation (APEC) 2012, Peer Review on Low Carbon Energy Policies in Thailand Final Report, the APEC Energy Working Group
APEC 2005, Thailand's Energy Efficiency Revolving Fund: A Case Study: Prepared for APEC Energy Working Group July 2005 DMG, Asia-Pacific Economic Cooperation

Pongpan Vorasayan (2012). "Thailand Experience on Building Energy Code". Department of Alternative Energy Development and Efficiency, Ministry of Energy, Thailand.

Twarath Sutabutr (2012). "Finance Energy Efficiency Projects through Financial Institutions: Energy Efficiency Revolving Fund". Department of Alternative Energy Development and Efficiency, Ministry of Energy, Thailand.

Christine Grüning, Carola Menzel, Tobias Panofen, and Laura Susanne Shuford (2012). "Case Study: The Thai Energy Efficiency Revolving Fund". Frankfurt School of Finance \& Management gGmbH 2012

APEC (2005). "Thailand's Energy Efficiency Revolving Fund: A Case Study". Prepared for APEC Energy Working Group July, 2005.

Ndiame Diop (2012). "Indonesia Economic Quarterly: October 2012, Maintaining resilience". World Bank. www.worldbank.org/indonesia 